made - the large carnivores and herbivores - would seem to have less potential except to provide pleasure and inspiration. But it is obviously good sense to try to preserve large areas of tropical forest and other habitats which contain thousands - perhaps millions - of undescribed species, whose economic potential has not been studied.

Finally, the Ehrlichs believe that unless we can maintain the diversity of the world's flora and fauna, the whole life-support system may break down. This is probably true, but the organisms which are the most important - the decomposers in the soil, insignificant parasitic insects, soil fungi and sewage organisms - are seldom the subjects of popular conservation programmes. The impoverishment of our fauna with the loss of the wolf, the bear and the wild boar has not had the effect of making farming in Britain less efficient quite the reverse.

So we must come to the conclusion that conservation is a far from simple subject. The economic and similar arguments often need to be qualified. Those based on the value of diversity are far from proven. Conservationists must avoid making statements which they know to be untrue in an attempt to obtain wider support from politicians and the general public. The most cogent reason for conservation, in my opinion, is that "man does not live by bread alone"; the general and aesthetic reasons have more validity than the economic.

Kenneth Mellanby's most recent book is Farming and Wildlife (Collins, 1981).

\title{
Fighting for the conservation of tigers
}

\section{Brian Bertram}

Saving the Tiger. By Guy Mountfort. Pp.123. ISBN US 0-670-61999-X; ISBN UK 0-7181-1991-6. (Viking/Michael Joseph: 1981.) \$16.95, £7.95.

THE tiger is a slim, dramatic animal, and it now has a book to match it. The numerous, large and well-printed colour plates are spectacular and superb. They do not leave a great deal of space for the authoritative text, in which the author summarizes our still scanty information on tigers, their appalling conservation plight and international attempts to prevent their extinction.

Despite the title, the tiger has not been saved, and it would be dangerous to think that it had been. Equally, it would now be much closer to extinction but for international efforts on its behalf. Guy Mountfort was both the catalyst and the power house in setting up Operation Tiger in 1972, under which the World Wildlife Fund raised nearly a million pounds for tiger conservation. He describes how the governments of India, Bangladesh and Nepal were persuaded to establish reserves for tigers, and other countries of Southeast Asia have since followed suit.

The hunting of tigers for sport is no longer a threat, thanks to national legislation in most of the countries concerned. The traffic in tiger skins for the fur trade has dwindled, thanks also to CITES, the Convention on International Trade in Endangered Species. Illegal killing of tigers is declining as local policing improves and as there is less direct contact between tigers and the local populace. The main threat nowadays is from loss of the forest habitat and the prey species on which tigers depend. Through the efforts of Guy Mountfort and others, this threat has been alleviated in many areas, and general public awareness of the plight of these wonderful animals has been raised.

What about future prospects? First, our priorities. With great difficulty and organization, large sums of money have been raised and thousands of square miles of tiger habitat protected. The total costs involved are equivalent to those needed to build a mere half-dozen miles of motorway. Which is more important? Should we have some form of conservation levy which because we human beings are so numerous would be paltry at the individual level?

Second, the status of tigers in their native reserves is relatively safe only so long as there is no breakdown of law and order in the countries concerned, and until human population pressures become irresistibly strong.

Third, although the many captive tigers in the zoos of the world are not a substitute for wild populations, they may well be a back-up. There should be tigers in the wild where they belong. But if the $350-400$ wild Siberian tigers or the $600-800$ wild Sumatran tigers are exterminated through human greed or folly, there are at least 800 Siberian and 150 Sumatran tigers in captivity. I am convinced that these could be used to re-stock areas from which wild tigers had been wiped out. Certainly, it would be difficult, and would need money, time and skill, and certainly there would be failures. But there is no reason in principle why, if necessary, reintroduction should not prove possible with tigers as it has with other large cats. We only hope that it does not become necessary. Guy Mountfort has done much more than most to help prevent it.

Brian Bertram is Curator of Mammals at the Zoological Society of London.
The sexes look at sex

\section{Adrienne L. Zihlman}

The Woman That Never Evolved. By Sarah Blaffer Hrdy. Pp.242. ISBN 0-674-95540-4. (Harvard University Press: 1981.) \$17.50, £12.25. The Evolution of Love. By Sydney L.W. Mellen. Pp.312. ISBN hbk 0-7167-1271-7; ISBN pbk 0-71671272-5. (W.H. Freeman: 1981.) Hbk $\$ 15.95, £ 8.50$; pbk $\$ 8.95$.

BOOKS on the evolution of human behaviour are often more interesting for the questions raised than for the answers proposed. This is particularly true when one compares the questions posed by male and female authors about the evolution of primate sexuality. The books under review provide a classic case study in contrasting, almost mutually exclusive, viewpoints.

During the 1960 s, male reconstructions of human evolution informed us that human hairlessness evolved to enhance front-to-front sex; that men's social and political clubs have sprung from the cooperative cameraderie of the male hunting groups that made our species successful millions of years ago; and that human females lost œstrus and became perpetually sexually receptive so as to keep males around to provide protection and meat from the hunt.

During the 1970s, women increasingly joined men in the game of replaying human prehistory. In place of the prevalent Manthe-Hunter scenario that put males centre stage and relegated passive, dependent females to the wings, waiting for the heroes' return, women anthropologists emphasized the important social and economic role of Woman-the-Gatherer. They also drew on sociobiological theory, which hypothesizes that the sex investing the most time and energy in raising the offspring makes the choice of mates. The central male role in the evolution of human culture and institutions was disputed by field observations on primates and on gatherer-hunters such as the !Kung San, revealing the pre-eminent involvement of females in obtaining and sharing food, choosing mates, socializing children, establishing and maintaining social networks, and using tools - in contrast with the earlier image of females as rather passive recipients of male sexual and hunting activities.

Sydney Mellen's The Evolution of Love and Sarah Hrdy's The Woman That Never Evolved provide examples of the male and female viewpoints of the 1980s. Both are concerned with an evolutionary overview of human nature, particularly sexual nature. Both use the theoretical framework of sociobiology, which attempts to explain contemporary human behaviour by genes that evolved millions of years ago. Mellen draws heavily on the fossil and archaeological record of the past 2-3 million years and does not dwell on non-human 
primates, whereas Hrdy goes deeply into the observed behaviour of females of numerous primate species and makes little reference to evolution as read from the fossil record.

According to Mellen, "love" emerged some three million years ago as an important adhesive force for human social groups and for successful child-rearing. His definition of love slides between conscious emotional attachment and sexual attraction; the large human brain is implicitly involved, but how human love differs from the emotional bonds of higher non-human primates is not always clear. His shortest chapter ( 7 pages) is titled "Love Between Parents and Children", the longest (46 pages), "The Enigma of Homosexual Love", by which he means male homosexual love.

Mellen's book belongs with the 1960s genre in that the framework is Man-theHunter and male choice of females. A central issue is male access to females, in order to be assured of their procreative potential, sexual receptiveness and "love". Hunting is credited with our acquisition of intelligence, cooperation, communication and food-sharing (old stuff); and (a new twist) men had many mates and natural selection enhanced "capacities for suspending fear" which resulted in the surviving hunters passing on "their courageous genes ... to many sons". Sociobiological theory tends to find a gene for every behaviour, and so Mellen explains that "finally the world came to be rather full of men whose chromosomes carried certain invidious genes for preferring young women", surely an unnecessary exegesis in a world in which, until very recently, few females or males lived beyond the age of 30 or 40 .

The Woman That Never Evolved challenges some of the sexual stereotypes that Mellen perpetuates, almost to the point of reversing them. Hrdy argues that the ubiquitous domination of females by males is a product of primate evolutionary history, as male domination is the rule (with few exceptions) among non-human primates. She brings together a broad array of up-to-date information on females of many species, from galagos to gelada baboons. Of particular interest are the chapters on monogamous primates, among which females enjoy relatively privileged positions, and on those species such as lemurs and squirrel monkeys in which there is no clear dominance of males over females.

Hrdy lays the greatest emphasis on female competition and status-seeking, as though to prove that women have inherited all the same undesirable traits that men possess and therefore should be equally successful. She states that "competition among females is central to primate social organization", and that "every female is essentially a competitive strategizing creature". Obviously, all members of a group "compete" to some extent for food, status and sexual partners, but, as in an atomic nucleus, the disruptive forces must be less than the cohesive ones if the group is to survive. In most species, male access to females is more limited than female access to males, hence male-male competition would be expected to be, and is observed to be, more intense than competition among females.

Hrdy's evolutionary construct is reminiscent of those of the 1960 s, with a sort of reversal of roles. It is females rather than males who are competitive and statusseeking, but instead of forming clubs and political parties, they use their sexuality to gain power and domesticate males and keep them from killing their infants. Hrdy's observation that "outside" male langurs will sometimes take over a troop and kill the offspring of lactating mothers - presumably so that they can reimpregnate these females with their own genes - is raised to the level of a paradigm: by the iron laws of sociobiology, primate males will try to "murder" offspring not their own and must be prevented from doing so by female strategems.

The woman that never evolved, according to Hrdy, is the woman invented by contemporary feminists: "created equal", having a natural sense of solidarity with other women and innocent of the male lust for power and status. Hrdy seems to assume that culture plays no role in the behaviour of women, and if certain kinds of behaviour are not found in other primates, they will not be found in humans.

I have improvised a dialogue between Mellen and Hrdy, to contrast their concerns and conclusions. Mellen: "Protohuman females were evolving in the direction of ever-increasing care and nurture of the young"'. Hrdy: "The vision of assertive, dominance-oriented females differs radically from existing stereotypes of female primates as non-stop mothers whose perennial preoccupation with nurturing offspring keeps them out of politics". Mellen doubts that pleasure from sexual intercourse is common for women. Hrdy retorts that female sexual activity is "assertive and temporarily insatiable".

Both of these books join the growing stacks of sociobiological attempts to integrate genes and human behaviour. They fail by ignoring the intervening levels that influence the outcome of behaviour development, socialization, symbols, ritual and values that are passed on nongenetically from generation to generation. Instead, they invoke hypothetical genes evolved either by hypothetical Pleistocene screenplays or deduced from selected observations on non-human primates and contemporary cultures. Mellen and Hrdy draw nearly opposite conclusions from their gene-based reconstructions. The book that has not yet been written is one that recognizes several levels of analysis, that integrates culture and biology and that interprets female and male behaviour in a mutually adaptive social system.

Adrienne L. Zihlman is a Professor of Anthropology at the University of California, Santa Cruz.

\section{Taste for travel and a naturalist's eye}

\section{A.J. Cain}

The Roving Naturalist: Travel Letters of Theodosius Dobzhansky. Edited by Bentley Glass. Pp.327. ISBN 0-87169-1396. (American Philosophical Society, Philadelphia: 1980.) $\$ 8$.

Theodosius Dobzhansky was a truly remarkable man, of great personal experience, shrewdness, humanity and intellectual ability. He wrote clear, vigorous, masculine prose, expressing the forceful thoughts of a first-class observer. This book of his letters and reminiscences is a delight; one can dip into it anywhere and find oneself in grand company. Even when his reactions are the usual ones - to the grandeur of tropical forests, the horrors of temperate-zone poverty or "lousy bureaucracy" - he expresses them with a freshness that always precludes banality. The book would be excellent at one's bedside for those with strength enough to ration themselves to a single letter.

There is an excellent, short biographical introduction by Bentley Glass which gives the major events in Dobzhansky's extraordinarily varied and interesting lifehistory. He was born in the Ukraine in 1900. In 1910 the family moved to Kiev. The boy, already a keen butterfly collector, went on a school excursion to the Caucasus; two years later he and a friend went off by themselves without parental permission to that fascinating region. His tastes for travel and entomology were already developed.

As a student at Kiev University, supporting his widowed mother, he had a difficult time towards the end of the Great War, and during the Revolution, in 1919, they experienced the Communist terror. Typhus, the invasion of the Polish Army, the death of his mother and severe privations in the winter of 1919-1920 were serious afflictions which he survived, becoming a private tutor, a graduate, an assistant to one of the professors of zoology and a tutor in the Workers' 